Journal of Research in Interprofessional

Practice and

Education

Vol. 5.1

May 2015
Journal of Research in Interprofessional Practice and Education (JRIPE)

Vol. 5.1

(C) 2015

Corresponding author: Marie-Claude Bouchard Email: Marie-C_Bouchard @uqac.ca

\section{Collaborative Practice in Secondary Schools in the Promotion of Healthy Eating and Physical Activity}

\author{
Marie-Claude Bouchard, BSc, MEd; Frances Gallagher, PhD, Associate \\ Professor; Hassan Soubhi, PhD, Associate Professor; Louis Bujold, \\ Associate Professor; Denise St-Cyr, Professor
}

\begin{abstract}
Background: Among 12 to 17 year-olds, overweight and obesity rates have more than doubled in the past 25 years. In Quebec, the government initiatives that have been implemented to promote healthy behaviours among young people require the collaboration of many stakeholders. The objective of this study was to describe collaborative practice in secondary schools promoting healthy eating and physical activity.

Methods and Findings: A descriptive multiple-case study was conducted in three Quebec secondary schools. The data collection methods consisted of a focus group, semi-structured individual interviews (21), observation of events involving collaboration among various school stakeholders (5), and document analysis (3). Qualitative analysis of intra-case and cross-case data carried out by more than one researcher helped identify emerging manifestations of collaborative practice.

Conclusion: Committing to projects, accepting tasks, and consulting with colleagues are some of the actions identified in school-based activities promoting healthy lifestyles. This study sheds light on the importance of collaborative practice in the promotion of healthy lifestyles among young people in a school setting. Keywords: Collaboration; Health promotion; School; Physical activity; Healthy eating
\end{abstract}

\section{Introduction}

According to the WHO, schools play an important role in the prevention of noncommunicable diseases associated with overweight by promoting healthy diets and physical activity [1]. Schools can reach young people from all backgrounds [2,3], and as a "second home," schools can be ideal places for working with youth. Furthermore, their educational mission requires that they provide their students with healthy and nutritious meals, [1] so schools can also play an important role in the adoption of healthy eating habits by offering young people a wider choice of healthy foods $[4,5]$. In addition, schools provide the global environment for the integration of interventions that promote physical activity [6]. The global environment refers to a set of ele- 
2

Promotion of Healthy Eating and Physical Activity in Schools

Bouchard, Gallagher, Soubhi, Bujold, \& St-Cyr

Journal of Research in Interprofessional Practice and Education

Vol. 5.1

May 2015 ments (physical, socio-cultural, political and economic) that can positively influence diet, physical activity, body image and self-esteem [7].

However, the collaboration of all school staff is necessary in the implementation of activities involving health promotion and disease prevention [8]. As a key member of the team, the school nurse must support promotional activities and work with the other staff members in the development, implementation, and evaluation of health programs [9].

Overweight and obesity among young people are a major health concern $[2,10]$. In Quebec, more than one in five youths aged 12 to 17 are overweight [11], and the increase in overweight, obesity, and chronic diseases among youths is strongly linked to dietary habits [5]. A survey conducted by the Réseau du sport étudiant du Québec [12] among 10,000 adolescents in secondary one, two, and three (grades 7-9), from November 2010 to January 2011, revealed that only 47\% eat fresh fruit daily and less than $55 \%$ eat vegetables. Young people report that they regularly consume sweets (76\%), salty snacks (64\%), fruit-flavoured beverages (61\%), fried food (52\%), and soft drinks (44\%). According to the Canadian Physical Activity Guidelines, youths aged 12 to 17 years should do a minimum of 60 minutes of moderate- to vigorousintensity physical activity daily [13] to gain the benefits of exercise, whether for an improvement in their health, a sense of well-being, or to maintain a healthy body weight [14]. Yet it seems that few young Quebecers meet these standards. In fact, there is a marked decrease in physical activity in early adolescence [15].

Given that lifestyle habits acquired in childhood tend to continue into adulthood [16], and lifestyle choices adopted during this transition period can have a lasting influence on health in adulthood $[17,18]$, it is important to encourage young people to adopt healthy habits. Indeed, such interventions constitute one of the keys to the future of public health [19] by preventing unhealthy behaviours from becoming fully established and more difficult to change [20]. The main determinants that we can act on to prevent weight-related problems are diet and physical activity [15,21]. Currently in Quebec, some initiatives target schools that are seen as an important component of a comprehensive health policy [1], and that can also have a significant impact on the eating habits and physical activities of youth, thereby helping prevent overweight and obesity.

As health issues are no longer the exclusive domain of health professionals but everyone's responsibility, teachers and physical educators are now responsible for health education in schools [22]. This paradigm shift requires the various stakeholders in education and health promotion [8] to share their expertise. Manifestations of collaboration among the stakeholders of a school can be found in two orientation documents, the Politique-cadre pour une saine alimentation et un mode de vie physiquement actif [23] and the Healthy Schools Approach [24].

The concept of collaboration is mainly documented from the perspective of collaborative work among professionals, particularly in the fields of health and education. In the health field, collaboration includes the exchange of information [25], the discussions aimed at achieving common goals [26], the sharing of work tools and discussion of cases [27, 28], the sharing of responsibilities [26], and visits to patients in 
3

Promotion of Healthy Eating and Physical Activity in Schools

Bouchard, Gallagher, Soubhi, Bujold, \& St-Cyr

Journal of Research in Interprofessional Practice and Education

Vol. 5.1

May 2015 hospitals and interprofessional meetings [29]. In the educational field, it involves meetings aimed at establishing a work structure, discussions, exchanges [30], sharing of tasks or materials, support among teachers, and organizing activities together [31]. Several determinants of collaboration have also been documented in the literature of health disciplines [32] and education [30], such as respect, confidence, leadership, and staff stability. As an example, leadership, an essential factor to effective teamwork [33], is not necessarily associated with a position of authority [34]. The nurse must assume her leadership role when it comes to school activities promoting health [9]. If she can develop good leadership, the school will benefit [35].

In schools, certain situations may require the collaboration of various categories of stakeholders, including teachers, health professionals, community planners, and parents. For example, in the section of the Quebec Education Program that deals with general health and well-being, the educational aim is to "ensure that students develop a sense of responsibility for adopting good habits with respect to health" [36, p. 23]. This goal "requires concerted action by all school staff, in collaboration with parents, health professionals, community planners and others in the school" [36, p. 23]. However, we know little about what is happening in terms of collaboration between the teaching and non-teaching staff in the promotion of healthy lifestyles in secondary schools.

The aim of this study is to describe how collaborative practice is displayed in secondary schools in the promotion of healthy eating and physical activity. The proposed definition of collaborative practices, inspired by D'Amour [37], is the voluntary commitment of a group of individuals from various areas of activity, working together to implement activities that promote healthy lifestyles among young people. This involves collaboration among various members of the school staff, such as the nurse, IT technician, and teachers. Since no study has been carried out on this subject, the first step was to document current practices. Therefore, the aim of this study was to describe collaborative practice among personnel from various secondary school fields working to promote a healthy lifestyle (healthy eating and physical activity) to prevent overweight and obesity. In this study, we asked two research questions, specifically:

1) When actions or interventions to promote healthy eating and physical activity are implemented, how do the subsequent collaborative practices manifest themselves in a school setting?

2) What are the potential components of an empirical model of collaborative practices in the school setting in promoting health habits?

\section{Methods}

A descriptive multiple-case study was conducted in three secondary schools in a region of Quebec (Canada). This type of research is appropriate for understanding a complex social phenomenon in context [38], when it is important to consider the experience of stakeholders. Furthermore, case study may lead to significant contributions to theory building [39]. Each case must be clearly defined and should contain one or more unit(s) of analysis linked to the research questions [38]. As part of this study, three cases-three regular public secondary schools-were selected using a 
Promotion of Healthy Eating and Physical Activity in Schools

Bouchard, Gallagher, Soubhi, Bujold, \& St-Cyr
Journal of Research in Interprofessional Practice and Education

Vol. 5.1

May 2015 purposeful sample. Each case consisted of two units of analysis. The first included general informants (teachers, non-teaching staff, a student council representative, a representative of the governing board, and members of the school administration) who were most likely to be familiar with promotion activities requiring collaboration and who would be able to inform the research team about the collaborative practices used at their school. Overall, approximately one hundred persons were suited to act as general informants in this study. The second unit of analysis consisted of healthpromotion activities for which there were key informants, events, and documents.

A total of 23 informants were interviewed and six activities and three documents (educational projects) were examined (Table 1). The selection criteria for general informants required that they be either 1) the holder of a regular or replacement position for at least one year in the school, or 2) a member of the governing board for at least one year. Activities were carefully selected with input from the general informants. They had to make significant use of collaborative practices that met four criteria: 1) promoting healthy lifestyles associated with healthy eating (HE) or physical activity (PA), 2) contributing to the prevention of overweight and obesity, 3) conducted within the school premises, 4) undertaken by stakeholders in the school. Figure 1 shows the processes of data collection and analysis.

\section{Table 1}

\section{Sources of information}

\begin{tabular}{|l|l|l|l|}
\hline Informants & CAS1 & CAS2 & CAS 3 \\
\hline General informants (GI) & $12^{*}$ & 2 & $2^{*}$ \\
\hline Key informants (KI) & 4 & $3^{* *}$ & 4 \\
\hline Activities & 2 & 2 & 2 \\
\hline Document & 1 & 1 & 1 \\
\hline $\begin{array}{l}* 2 \text { GI cases 1 and 1GI case 3 were also key informants (26 - 3 }=23) \\
* * \text { A key informant case 2 was responsible for two activities }\end{array}$ \\
\hline
\end{tabular}

Several data collection methods were used, including a focus group, semi-structured individual interviews, non-participant observation, and document review. The tools used for this purpose were interview guides, a data entry grid, an observational grid, field notes, data sheet, and the principal researcher's logbook. Data were collected from the general and key informants and during events that were held as part of the fieldwork from April 2011 to June 2012.

Data were collected using focus groups in order to isolate collaborative practices where at least two people were involved in health promotion activities. A focus group was conducted for Case 1. Unable to attend the discussion group for professional reasons, three other general informants were interviewed individually with the same interview guide used for the group discussion. This meeting, which 
5

Promotion of

Healthy Eating and Physical Activity in Schools

Bouchard, Gallagher, Soubhi, Bujold, \& St-Cyr
Journal of Research in Interprofessional Practice and Education

Vol. 5.1

May 2015

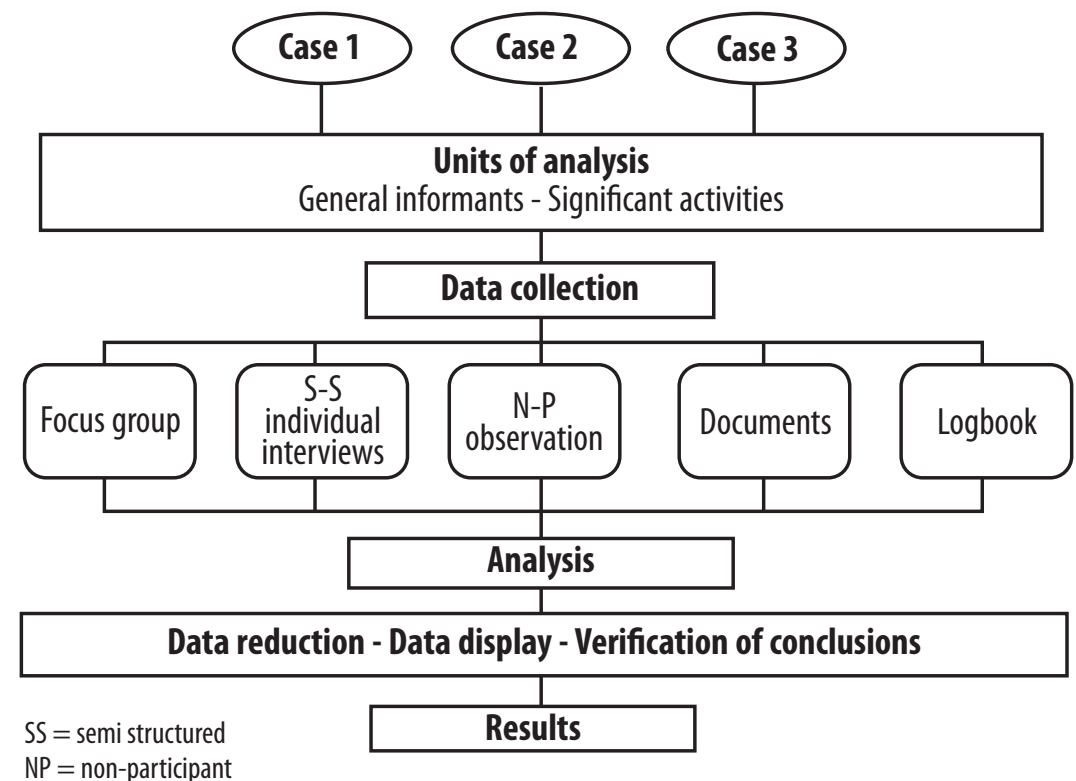

Figure 1

\section{Data collection and analysis process}

involved nine general informants and lasted 90 minutes, aimed to identify activities promoting healthy eating and physical exercise that involved collaborative practices at the school. This time has allowed each participant to express and validate that the activities identified by his colleagues included collaborative practices. For Cases 2 and 3, the school principals directed the primary author to general informants who could provide her with information identifying activities with collaborative practices individually rather than in a focus group. These general informants were interviewed in semi-structured individual interviews with the same interview guide that was used for the focus group discussions [39]. In summary, nine general informants participated in a focus group and 7 general informants participated in one on one semistructured interviews to identify activities promoting healthy eating and physical exercise that involved collaborative practices at the school.

For each targeted health promotion activity, semi-structured individual interviews were conducted among the key informants of these activities; the first one lasted about 45 minutes and the second about 20 minutes. The purpose of these interviews was to explore how collaborative practices were displayed in secondary schools and the factors that could influence these practices in the implementation of activities promoting the adoption of healthy lifestyles. The purpose of the second interview was to confirm the results of the first interview and to continue to explore the collaborative practices [40]. All interviews, including the focus group, were recorded in digital audio format.

To provide an overview of each targeted activity, events were observed, for example, by being present onsite for two hours during a cycling or gym activity, or attending an activity planning meeting. Each of the six activities listed included several events (discussion meeting, planning meeting, preparation of premises and equipment). In this 
6

Promotion of Healthy Eating and Physical Activity in Schools

Bouchard, Gallagher, Soubhi, Bujold, \& St-Cyr

Journal of Research in Interprofessional Practice and Education

Vol. 5.1

May 2015 study, five events promoting healthy lifestyles, which were part of the schools' regular programming and which lasted on average 60 minutes, were observed.

The document review aimed to supplement data from other sources and to provide information about the various events associated with the activity (planning, implementation, evaluation). In this multiple-case study, the key informants were not able to provide us with documents that could have helped define the context in which the activities took place, nor were they able to identify the collaboration indices among stakeholders. However, other internal school documents, such as the school's educational project that outlines the aims and actions related to the school's mission (to educate, socialize, and qualify students) [41], were helpful in this regard. Other relevant documents, such as the list of extracurricular activities and minutes of meetings, were useful to the study for what they added to the description of each case [40].

A logbook was used to record information related to methodological aspects of the study, such as decisions, questions, and drafts of explanations, and overall descriptions and personal reflections and impressions from the primary author. The logbook also helped establish links between various observations or methods, raise awareness of bias, and increase the validity of observations and the depth of our interpretations [42]. The field notes written during non-participant observation of events were useful for describing, among other things, physical locations, the role of participants, and interactions between them [43]. A socio-demographic questionnaire was completed by each participant. The questionnaire was designed to collect information on gender, the position held at the school, the number of years of experience in this position, and the number of years of experience at the school. These specifics allowed us to describe the participants' characteristics [40] (Table 2).

Qualitative data analysis, as suggested by Yin [39], was inspired by the work of Miles and Huberman [44] and was conducted using a mixed approach. This was a continuous iterative endeavour [44], with data collection and analysis conducted simultaneously. Three concurrent flows of activity occurred during this phase. The first flow of activity, corresponding to data reduction, focused on reading and rereading Case 1 transcripts created by the primary author and the co-researchers (FG, DST). A grid, initial code, and thematic code were then developed. The grid consisted of codes derived from the literature and codes that emerged during analysis. The evolving grid was validated by three authors (MCB, FG, DST) at several points during the coding stage. The data collected for each of the three cases was codified by the primary author and by at least one co-researcher (FG or DST). At the end of this first exercise, which resulted in a set of initial codes, a thematic code was created to reduce the data to a smaller number of units $[40,44]$.

The second flow of activity, data display, focussed on the creation of conceptual matrices integrating interview and observational data for each case (intra-case analysis). The matrices helped access information quickly, integrate results from all data sources [44], view all data at a glance and create links between categories [44]. Intracase analysis identified the context, the determinants, the characteristics related to the events of each case and the role of the school nurse. Cross-case analysis shed light on the similarities and differences of the three cases [44], facilitating interpretations 
7

Promotion of

Healthy Eating and

Physical Activity in

Schools

Bouchard, Gallagher, Soubhi, Bujold, \& St-Cyr

Journal of Research in Interprofessional Practice and Education

Vol. 5.1

May 2015 and conclusions. This analysis, stemming from all the data collected through semistructured interviews, observation and document analysis for each of the three cases, required some standardization of matrices in order to juxtapose the results $[40,44]$.

The third flow of activity, verification of conclusions, was conducted during the analysis by holding discussion meetings (MCB, FG, DST) and by referring frequently to the transcripts to ensure concordance between, on the one hand, the observations and content of the interviews, and on the other, the results from each stage of the analysis process. In addition, understanding the perspective of key informants and the meaning they gave to their collaborative experiences was confirmed by conducting validation and in-depth interviews and co-encoding data [40].

This study was approved by the Research Ethics Committee of the Centre de recherche clinique Étienne-Le Bel du Centre hospitalier universitaire de Sherbrooke.

\section{Results}

\section{Cases characteristics}

The study was conducted in a French-speaking region of Québec (Saguenay) with a total estimated population of 147,000. This region, located 250 kilometres from Québec City, is divided into three districts and has several outlying areas. Known for its green spaces and many bodies of water, the region is very conducive to outdoor activities. Among other things, the young people of the region have access to outdoor facilities such as skateboard ramps, bike paths, and parks with bodies of water where they can enjoy water sports (swimming, kayaking, canoeing). They also have sports centres where they can participate in various activities, including ice sports. When they have completed primary school, the young people of the region can register for a regular or other secondary school program, such as Sport-Art-Études or the International Education Program. At the end of secondary five (grade 12), they can continue their studies at one of two general and vocational colleges (CEGEP) to obtain a college degree or at a vocational training centre for a professional diploma. Young people who wish to pursue university studies also have access to a regional university offering several undergraduate and graduate programs. The three cases studied (Case 1, Case 2, and Case 3) were three public secondary schools within a $25 \mathrm{~km}$ radius of one another that shared common characteristics. Since the study was conducted in a small area and the schools (Cases) were located close to one another, the specific characteristics (actual study programs, detailed provenance of the clientele, title of the activity) will not be disclosed to protect the anonymity of the cases and participants.

The three schools had more than 1,000 students from urban and rural areas. They provided cafeteria and canteen services; several extracurricular activities at lunchtime and after school; an infrastructure for conducting activities at school (gymnasiums, swimming pool, and fields [two out of three]); and public transportation at lunch hour for students living not far from the school. In all three schools, a school nurse was present five days a week.

A total of six health promotion activities, or two per case, were examined. These significant activities were not part of the physical education and health program, and required the involvement of several members of the teaching and non-teaching staff 


\section{JRIPE}

8

Promotion of

Healthy Eating and Physical Activity in Schools

Bouchard, Gallagher, Soubhi, Bujold, \& St-Cyr

[36, p. 23]. Four activities focused on physical activity, one on healthy eating and one on the creation of a health committee at the school. The characteristics of these activities are presented in Table 3. Results of this study are based on empirical manifestations of collaborative practices during these activities. For Cases 2 and 3, at least one of the two activities was conducted in May, which, in Québec, is the physical activity and student sports month.

Table 2

\section{Characteristics of cases}

\begin{tabular}{|c|c|c|c|}
\hline & CAS 1 & CAS 2 & CAS 3 \\
\hline General informants & 12 & 2 & 2 \\
\hline Females & 6 & 1 & 1 \\
\hline Teaching staff & 6 & --- & --- \\
\hline $\begin{array}{l}\text { Non-teaching staff } \\
\text { (Nurse, student-life facilitator, IT technician, social worker, and others) }\end{array}$ & 6 & 2 & 2 \\
\hline Key informants & 4 & 4 & 4 \\
\hline Females & 1 & 3 & 1 \\
\hline Teaching staff & 1 & 1 & 1 \\
\hline $\begin{array}{l}\text { Non-teaching staff } \\
\text { Nurse, student-life facilitator, IT technician, social worker and others }\end{array}$ & 3 & 3 & 3 \\
\hline \multicolumn{4}{|l|}{ Years of experience } \\
\hline$\cdot<1$ & 1 & --- & --- \\
\hline •11-15 & --- & 1 & --- \\
\hline$\cdot>20$ & 3 & 3 & 4 \\
\hline \multicolumn{4}{|l|}{ Topics covered in the school's educational project } \\
\hline Health promotion & No & No & Yes \\
\hline Healthy eating & No & No & Yes \\
\hline Physical activity & No & No & Yes \\
\hline
\end{tabular}

Journal of Research in Interprofessional Practice and Education

Vol. 5.1

May 2015

\section{Intra-case analysis}

\section{Manifestations of collaborative practices}

Analysis of the data revealed many expressions of collaboration. The only documents that were related to the health promotion activities observed included the edu- 
9

Promotion of Healthy Eating and Physical Activity in Schools

Bouchard, Gallagher, Soubhi, Bujold, \& St-Cyr

cational projects of the three schools and a thank you note sent to the stakeholders and participants involved in the planning and implementation of activities.

Despite the different contexts for each of the six significant activities examined, we were able to identify many expressions of collaborative practice common to all three cases (Table 4). To avoid duplication of findings common to the six activities studied, an in-depth description of empirical manifestations identified for one activity of Case 1 is presented based on all the data collected for this activity. A few manifestations of collaboration of Cases 2 and 3 are presented in Table 5.

Table 3

\section{Characteristics of activities}

\begin{tabular}{|c|c|c|c|c|c|}
\hline Case & Activity & Subject & Objective & Persons in Charge & Frequency \\
\hline \multirow[t]{2}{*}{ Case 1} & Activity 1 & $\begin{array}{l}\text { Physical activity } \\
\text { (cycling) }\end{array}$ & $\begin{array}{l}\text { Conduct a fundraising } \\
\text { campaign as a pretext to } \\
\text { promote physical activity }\end{array}$ & $\begin{array}{l}\text { Teaching staff (1) } \\
\text { Non-teaching staff (1) }\end{array}$ & $\begin{array}{l}\text { For one week of the school year, from } \\
7: 45 \text { a.m. to } 4 \text { p.m. Each group of } \\
\text { students cycles for a minimum of } 15 \\
\text { minutes per week }\end{array}$ \\
\hline & Activity 2 & $\begin{array}{l}\text { Creating a health } \\
\text { committee }\end{array}$ & $\begin{array}{l}\text { Implement health-promotion } \\
\text { activities in schools }\end{array}$ & $\begin{array}{l}\text { Teaching staff (4) } \\
\text { Non-teaching staff (5) }\end{array}$ & Start of school year and throughout \\
\hline \multirow{2}{*}{ Case 2} & Activity 1 & $\begin{array}{l}\text { Walking } \\
\text { (outside) }\end{array}$ & $\begin{array}{l}\text { Encourage young people to be } \\
\text { physically active during their } \\
\text { lunch hour }\end{array}$ & Non-teaching staff (2) & Throughout the school year \\
\hline & Activity 2 & $\begin{array}{l}\text { Physical activity } \\
\text { (aerobics) }\end{array}$ & $\begin{array}{l}\text { Encourage young people to be } \\
\text { physically active during the } \\
\text { exercise month }\end{array}$ & $\begin{array}{l}\text { Teaching staff (1) } \\
\text { Non-teaching staff (1) }\end{array}$ & $\begin{array}{l}\text { One day a year in May, each group of } \\
\text { students takes part for } 30 \text { minutes }\end{array}$ \\
\hline \multirow[b]{2}{*}{ Case 3} & Activity 1 & $\begin{array}{l}\text { 24-hour activity } \\
\text { (cycling, walking, } \\
\text { sports in } \\
\text { gymnasium) }\end{array}$ & $\begin{array}{l}\text { Encourage young people to be } \\
\text { physically active during } \\
\text { exercise month }\end{array}$ & $\begin{array}{l}\text { Non-teaching staff (3) } \\
\text { Teaching staff (4) }\end{array}$ & 24 consecutive hours in May \\
\hline & Activity 2 & $\begin{array}{l}\text { Healthy diet } \\
\text { (Selecting food } \\
\text { based on } \\
\text { nutritional value, } \\
\text { preparing food) }\end{array}$ & Develop healthy eating habits & $\begin{array}{l}\text { Teaching staff (1) } \\
\text { Non-teaching staff (1) }\end{array}$ & $\begin{array}{l}3 \text { hours per 9-day cycle of the school } \\
\text { year }\end{array}$ \\
\hline
\end{tabular}

Journal of Research in Interprofessional Practice and Education

Vol. 5.1

May 2015
For Case 1, a school's humanitarian cause to raise money to help a student and his family resulted in a major activity (cardio-cycling) that took place over a whole week of the school year in the central corridor of the school. According to the perception of all general informants of a focus group and in semi-structured individual interviews, this activity served not only as an example of collaboration among several people, but as a source of pride for the entire school community: "They were very happy ... I can tell you we worked hard ... everyone worked hard and we were all very proud because everyone responded well" (Martin). 
Promotion of Healthy Eating and Physical Activity in Schools

Bouchard, Gallagher, Soubhi, Bujold, \& St-Cyr

Journal of Research in Interprofessional Practice and Education

Vol. 5.1

May 2015

\section{Journal of Research in Interprofessional Practice and Education}

Empirical manifestations of collaboration were translated into actions by those involved in the activity. These manifestations, presented in Table 4, are the subject of the descriptive narrative in the text that follows.

Table 4

\section{Manifestations of collaboration in activities to promote healthy eating and physical activity in secondary schools}

\begin{tabular}{|l|l|}
\hline Commit & $\begin{array}{l}\text { to serve a cause or a project. Also includes agreeing to perform a task, to take } \\
\text { responsibility, to accept an idea. }\end{array}$ \\
\hline Communicate & $\begin{array}{l}\text { to exchange guidelines and information with colleagues, management and agencies } \\
\text { (internal/external). Also means the action of consulting colleagues or management to seek } \\
\text { advice and using inclusive language such as "we." }\end{array}$ \\
\hline Coordinate & to motivate, organize activities, help make decisions. \\
\hline
\end{tabular}

The two key informants we met to discuss this activity were Martin ${ }^{1}$ (a teacher) and David (not a teacher). The purpose of the activity was to support a cause while promoting physical fitness. The activity in Case 1 started when the teacher, Martin, was told about the plight of one of his students and her family. Moved by compassion, Martin spoke to David: "So M ... asked me ... what can we do? We're thinking ... we need to find an activity." David, very concerned about the situation, mentioned it to Serge (teacher and long-time bike enthusiast) during a chat in the corridor. After further discussion among Martin, David, and Serge, it was decided to propose a cardio-cycling activity that would involve the participation of all students at the school. Martin and David consulted with colleagues and the school principal to obtain approval or responses: "We'll go see the Phys. Ed. teachers ... we'll talk to them ... should we have a week of cycling?" (David). After consultation among the initiators of the project, members of the administration, and physical education and health teachers, the idea of a day of cardio-cycling was chosen as an activity that would be spread over a full week of the school year so that all students could have the opportunity to cycle: "We wanted all of the school's more than 1,000 students to participate" (Martin). Without hesitating, David expressed a desire to become involved in the project by proposing: "For this cause I'd offer to cycle for a day for seven hours."

A few days later, after hearing about the project, the physical education and health teachers became very interested in the project and decided to commit to it: "The physical education teachers met and said ... we're getting involved" (Martin). One physical education and health teacher actually became directly involved by serving as a model for the students:

A physical education teacher also cycled all day ... so that students could see how it works and how you can cycle for a long time and be in shape. He didn't talk ... but the students saw him, all the groups, who came at 15 minute intervals, saw that he was cycling constantly. (Martin) 
11

Promotion of Healthy Eating and Physical Activity in Schools

Bouchard, Gallagher, Soubhi, Bujold, \& St-Cyr

Journal of Research in Interprofessional Practice and Education

Vol. 5.1

May 2015
Martin reported that many people, members of the teaching and non-teaching staff, had accepted duties and responsibilities related to the activity. The physical education and health teachers agreed to create a schedule for five school days so that each student had the opportunity to cycle for at least 15 minutes during their physical and health education class. In addition to the physical education and health teachers, other members of the teaching and non-teaching staff accepted tasks associated with the project. For instance, those in charge of the school's fitness room, who had experience in cardio-cycling, agreed to help out the physical and health education teachers: "Someone had to take over for professional reasons and Mr. Tremblay and people from the fitness room did it; they did a great job." Others in charge of facility maintenance agreed to see to the maintenance of the equipment used for the duration of the activity: "the maintenance staff turned up to clean the bikes and to put things back."

Another member of the non-teaching staff, the head of audiovisual, agreed to set up a giant screen that showed a virtual path for cyclists and to install the equipment required to broadcast music throughout the activity "with a TAC [audiovisual equipment] system that Mr. Charles, the young audiovisual sound system guy, had" (Martin). Several people opened lines of communication to exchange or share information about the activity "so that each of the teachers could tell their colleagues what was coming up.... And we met with all the classes and kept them informed" (David). When they had to recruit colleagues to get involved in activities, "if we involved as many people as possible and met with them, we kept them informed because it was all about communication, the communication strategy was to get people involved in the project" (Martin). Martin also made phone calls to get the support he needed from internal and external bodies: "I called one of the people in charge of sports activities at the school board and it took five minutes" for confirmation that bicycles would be loaned for the activity. Another recurring manifestation of collaboration was the use of inclusive language. The key informants we interviewed used the term "we" (in French nous or on) inclusively and repeatedly in describing the various events related to the activities, to indicate that several people were involved: "We met with all the students" (document). "Then M ... asked what can we do? ... we'll try to find something to motivate them" (David).

Martin and David coordinated or organized the activities for this event:

We coordinated all of this, but it was the Phys. Ed. and health education teachers who were actually with the students; so we had to make sure the schedule was followed, and also oversee the participation, the supervision and the shifts of the students as well as the transitions between groups." (Martin)

Another excerpt suggests that Martin had many other responsibilities: "I had to make sure that everything was coordinated with the delivery of bikes, the schedule, contact with the teachers, raising awareness, incoming staff ..."

It was not possible to analyze a written document specific to the significant activity in Case 1 since no document was produced. We examined the school's educa- 


\section{JRIPE}

12

Promotion of Healthy Eating and Physical Activity in Schools

Bouchard, Gallagher, Soubhi, Bujold, \& St-Cyr
Journal of Research in Interprofessional Practice and Education

Vol. 5.1

May 2015 tional project to identify references to health-promotion activities at the school, but found none.

Table 5

\section{Manifestations of collaboration in activities to promote healthy eating and physical activity in secondary schools : Cases 2 and 3}

\begin{tabular}{|c|c|}
\hline Commit & \\
\hline & $\begin{array}{l}\text { "They knew I wouldn't refuse and would get on board right away." } \\
\text { "I prepare it and do it on a voluntary basis. I mean, it's not part of my job." } \\
\text { "If you want to promote it and get people to try it, you have to take part." } \\
\text { "We have a Phys. Ed. teacher who works with groups of troubled youth, and also a staff } \\
\text { member who gets involved. We have special education teachers involved with youth groups } \\
\text { and things like that." } \\
\text { Monique (Case 2) }\end{array}$ \\
\hline & $\begin{array}{l}\text { "Some people from the committee help with the activity and it happens during the lunch } \\
\text { hour. Some are more interested in food and some more in physical activity." } \\
\text { "Madeleine (Case 3) } \\
\text { "When I suggested this ... to give him a helping hand, perhaps I kind of had a more global } \\
\text { vision of the logistics. I suggested going to the physical education department and the } \\
\text { teachers got on board straightaway." } \\
\text { Two people in the group agreed to develop a schedule. } \\
\text { Two people in the group offered to take care of the official ceremony. } \\
\text { Observation \#1(Case 3) } \\
\text { Observation \#2 (Case 3) }\end{array}$ \\
\hline \multicolumn{2}{|l|}{ Communicate } \\
\hline & $\begin{array}{l}\text { "What we do is promote it through the teachers." } \\
\text { "... so we said, what can we do to put on an outstanding activity that will set us apart from } \\
\text { everything else that's going on." } \\
\text { Monique (Case 2) }\end{array}$ \\
\hline & $\begin{array}{l}\text { "... still reported to the full committee at the meeting." } \\
\text { "We aimed for what we wanted people to taste and what we wanted." } \\
\text { "We made all kinds of dishes, dishes that young people like, but we added vegetables and } \\
\text { had people taste them." } \\
\begin{array}{l}\text { "When the rest of us went to present it to them, the committee loved it." } \\
\text { Each reported on their activities or mandates for which they were responsible. } \\
\text { Observation \#2 (Case 3) }\end{array}\end{array}$ \\
\hline
\end{tabular}




\section{JRIPE}

13

Promotion of Healthy Eating and Physical Activity in Schools

Bouchard, Gallagher, Soubhi, Bujold, \& St-Cyr
Journal of Research in Interprofessional Practice and Education

Table 5 (continued)

\begin{tabular}{|l|l|}
\hline Coordinate & \\
\hline & $\begin{array}{l}\text { Interviewer: Who organized it? You? } \\
\text { "Yes, with Mrs...." } \\
\text { "We looked at her availability so that she could be with a group, or a time when she had no } \\
\text { classes, and the School Board came in the morning to give me a demonstration." } \\
\text { Monique (Case 2) }\end{array}$ \\
\hline & $\begin{array}{l}\text { "I made sure that for each project there was a person responsible, and that he or she would } \\
\text { report to the team. So I made sure that all these links ... I made sure of the quality of the } \\
\text { links, I would say." } \\
\text { "I do a lot of ... I delegate a huge amount. Also ... just because I handled the coordination, } \\
\text { doesn't mean I wouldn't go into the field ..." }\end{array}$ \\
\hline
\end{tabular}

\section{Cross-case analysis}

Cross-case analysis allowed us to group together manifestations of collaborative practice from all the data collected for the three cases and to propose potential components of an empirical model of collaborative practice. Despite the various contexts for each of the six significant activities examined, we were able to identify many manifestations of collaborative practice common to all three cases.

\section{Determinants of collaborative practice}

Several determinants of collaborative practice, as perceived by the informants, were also identified. These determinants are factors that may have a favourable or unfavourable (obstacle) impact on collaborative practices in promoting healthy eating and physical activity. They are the subject of another publication, but because they are potential components of the proposed empirical model of collaborative practices, we present them briefly with excerpts in Table 6. These are classified under three headings, as they are associated with 1) the individuals (commitment, knowledge of one's role, recognition and understanding of the role of other individuals, interest, volunteering); 2) the team (common goal/common vision, respect, trust, time, leadership); and 3) the organization (internal support, external support, team stability) [40].
Journal of Research in Interprofessional Practice and Education

Vol. 5.1

May 2015 
14

Promotion of Healthy Eating and Physical Activity in Schools

Bouchard, Gallagher, Soubhi, Bujold, \& St-Cyr
Journal of Research in Interprofessional

Practice and

Education

Vol. 5.1

May 2015
Table 6

\section{Determinants of collaboration in activities to promote healthy eating and physical activity in secondary schools}

\begin{tabular}{|c|c|}
\hline \multicolumn{2}{|r|}{ Individuals } \\
\hline Commitment & "I certainly put a lot of effort into it because I like it, I believe in it and I work hard on it." Robert (Case 1) \\
\hline Interest & “We need teachers, principals and young people to be interested." Martin (Case 1) \\
\hline Volunteering & "If people come because they feel obligated... that's no good." Martin (Case 1) \\
\hline Knowledge of one's role & "You have to play your part and go there and say...I'm here for this." School Nurse (Case 1) \\
\hline $\begin{array}{l}\text { Understanding and } \\
\text { recognizing the role of } \\
\text { others }\end{array}$ & "You can't do this alone ... and the teachers knew exactly what they had to do." Martin (Case 1) \\
\hline Open to change & "So I think we must be open to change, and I also think we should be positive." René (Case 3) \\
\hline \multicolumn{2}{|r|}{ Team } \\
\hline Common purpose & $\begin{array}{l}\text { "There was a purpose to it, there was a cause, and at the same time it gave us a reason to motivate students } \\
\text { to be physically active." David (Case 1) } \\
\text { The purpose of the meeting was emphasized from the beginning: Planning } 24 \text { hours of exercise. Observation } \\
\text { \#2 (Case 3) }\end{array}$ \\
\hline Time & $\begin{array}{l}\text { "You have to take the time for it to be well organized ... well planned." Martin (Case 1) } \\
\text { The time spent in the meeting was one hour and outside the classroom. Observation \#1 (Case 3) }\end{array}$ \\
\hline Trust & "I'm very, very close; we do many, many things together." Charlotte (Case 2) \\
\hline Respect & Everyone speaks after asking to do so and respects the right of others to speak. Observation \#1 (Case 3) \\
\hline Leadership & $\begin{array}{l}\text { "But next year, I would like to reach out to the community more. I'll go to see businesses." Gabriel (Case 3) } \\
\text { "Well, that's because it takes someone who can argue the case." School Nurse (Case 2) }\end{array}$ \\
\hline \multicolumn{2}{|r|}{ Organization } \\
\hline $\begin{array}{l}\text { Support of internal } \\
\text { bodies }\end{array}$ & $\begin{array}{l}\text { "And we get very good cooperation from the fitness room downstairs, and Mr. Rinfret [fictitious name of } \\
\text { fitness room manager] also helps us a lot there." Martin (Case 1) } \\
\text { "So I think it's important that principals follow the teachers and give them a helping hand and make things } \\
\text { easier ..." René (Case 3) }\end{array}$ \\
\hline Team stability & $\begin{array}{l}\text { "I have all the same members who were with me last year." Robert (Case 1) } \\
\text { "This is likely to change each year, but since the committee has existed, it's been like that...but there is one } \\
\text { person who has always been there." Madeleine (Case 3) }\end{array}$ \\
\hline Union rules & $\begin{array}{l}\text { "There are those who stick to the collective bargaining agreement...wet blankets, they're there too." Martin } \\
\text { (Case 1) }\end{array}$ \\
\hline Perception of the activity & $\begin{array}{l}\text { "This is to prove to them...that a healthy mind in a healthy body...that it works." } \\
\text { Maxim (Case 3) }\end{array}$ \\
\hline Financial resources & $\begin{array}{l}\text { "As you know, one of the problems we have in schools is lack of money to organize because budgets are } \\
\text { limited." Martin (Case 1) }\end{array}$ \\
\hline
\end{tabular}




\section{JRIPE}

15

Promotion of Healthy Eating and Physical Activity in Schools

Bouchard, Gallagher, Soubhi, Bujold, \& St-Cyr

\section{Proposed model of collaborative practices}

Figure 2 presents the potential components of an empirical model of school-based collaborative practices in the promotion of healthy eating and physical activity. This proposed model highlights the empirical manifestations of these practices and their determinants in the three cases of the study. The school at the centre of the model is a common place that houses all school actors (group of people in front of the school). The health promotion (HE and PA) context of this study and the collaborative practices (determinants and events on the ground) are grouped on either side of the school. The importance of taking into account the global environment of the school in the activities of health promotion is represented by an oval that integrates all the components. The global environment can promote the practice of physical activity and improve healthy eating. For instance, interest (determinant) in one type of activity can cause a person to commit (manifestation) to the activity. In contrast, a person can communicate with the principal and with colleagues (manifestation) to get financial support, equipment, or simply to clarify its role and that of others (determinant).

\section{Figure 2}

\section{Proposed model of school-based collaborative practices promoting healthy eating and physical activity}

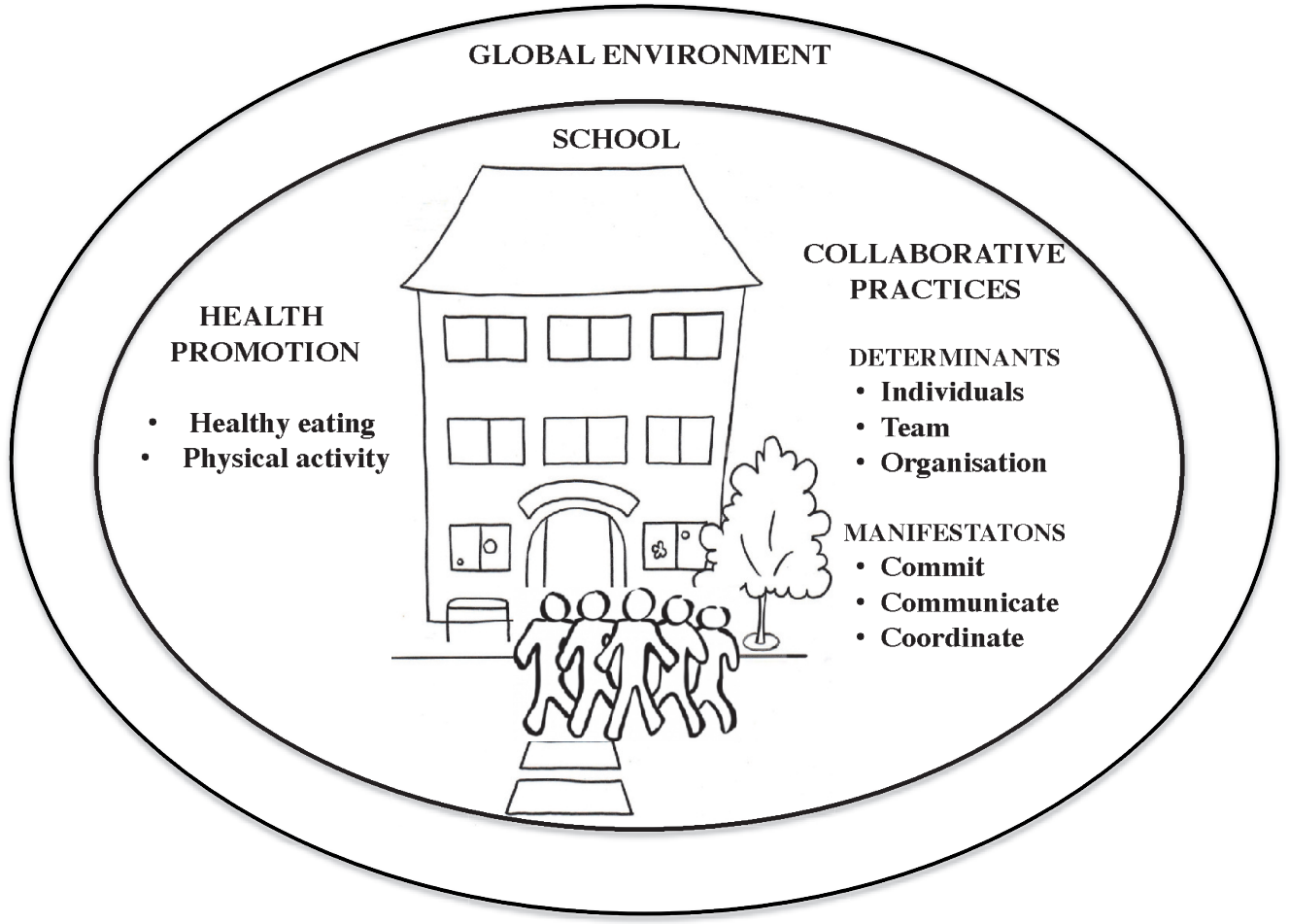

Some of the determinants in the proposed model relate more to the individual while others relate to the team or the organization. Therefore, we propose a classification under three headings. The first heading is assigned to determinants associated with individuals (engagement, knowledge of one's role, understanding and recognition of the role of others, interest, volunteering); the second to determinants related 
16

Promotion of Healthy Eating and Physical Activity in Schools

Bouchard, Gallagher, Soubhi, Bujold, \& St-Cyr

Journal of Research in Interprofessional Practice and Education

Vol. 5.1

May 2015 to the team (common purpose, respect, time, leadership); and the third to determinants related to the organization (internal and external bodies of support, team stability). The manifestations were also classified under three headings. The first heading, commitment to a project, had sub-manifestations that could be linked to an action such as accepting a task or responsibility; the second heading, communication, also had sub-manifestations, such as consulting with colleagues and using inclusive language, while the third was co-ordination of an activity or project.

\section{Discussion}

This study provides new information about a subject that has been poorly documented to date: collaborative practices in promoting healthy eating and physical activity. Practices observed in the field are manifestations of collaboration that highlight the shared responsibility for health, as proposed in the Quebec education reform [8]. Moreover, despite the recommendation of the Quebec Ministry of Education to include broad areas of learning (that is, those representing significant challenges for both individuals and communities) as a basis for a school educational project [36], an analysis of the educational projects in the three cases found initiatives relating to the promotion of health, healthy diet, and physical activity in only one case (Case 3). However, it was clear that despite the absence of explicit guidelines on promoting health in the educational projects in Cases 1 and 2, there were many collaborative practices expressed in the activities examined, and more specifically, for meaningful activities aimed at promoting physical activity.

With regard to the first research question that focused on manifestations of collaborative practices in promoting a healthy lifestyle (diet and physical activity) in schools, this study, one of the first on the subject, has revealed several manifestations of this collaboration thanks to the variety of data collection methods used (semistructured interviews, observation, logbook, field notes, documents). These were manifestations of school-based collaborative health-promotion activities that reflected a shared responsibility for health education among all members of the school staff [22], as well as the pooling of expertise among the school's various stakeholders. These manifestations differ from those reported in the areas of health and education except for the manifestations "to accept tasks or responsibilities" and "to communicate" [30]. Many manifestations of collaboration are listed in the health and educational fields. For instance, the numerous manifestations in the health field include discussions aimed at achieving common goals [26], the sharing of work tools [27], visiting patients hospitalized in care facilities and participating in interprofessional meetings [29], seeking the expertise of other individuals [27], and sharing responsibilities [26]. The manifestations in the educational field, on the other hand, include establishing a work structure [30], providing mutual support among teachers, and collaboratively organizing educational activities [31].

At first glance the manifestations from the health and education fields appear to differ, but they bear some similarities: 1) holding meetings dedicated to professionals and 2) holding meetings to share information. However, the manifestations differ with respect to the reason for the collaboration. In healthcare, for instance, the pur- 
17

Promotion of Healthy Eating and Physical Activity in Schools

Bouchard, Gallagher, Soubhi, Bujold, \& St-Cyr

Journal of Research in Interprofessional Practice and Education

Vol. 5.1

May 2015 pose of meetings is to share information about patients, whereas in education, the purpose is to support teachers in various ways. For the most part, the manifestations specific to health and education differ from those that have been identified in this study, in which collaborative practices were closely observed for ad hoc-therefore less structured-initiatives. Ad hoc initiatives, however, can present both strengths and limitations. In Case 1, the humanitarian cause that served as the pretext for the activity was a strength in the sense that it was a significant source of motivation for all stakeholders. However, other aspects of this activity could represent limitations, such as minimal time to organize and to draft orientation documents. The lack of time to organize meant that the collaborators' research and planning activities were carried out during discussions in the corridor and no documentation was produced. In addition, this study identified an example of collaboration not documented in the literature consulted, namely the use of inclusive language. The use of "us" in speech was sometimes combined with other manifestations of collaboration such as "we consulted" and "we communicated." This reflects the degree to which the stakeholders took responsibility for the project.

There are also similarities and differences between the manifestations of collaboration in the literature and those identified in this study. Communication mechanisms and communication skills are important determinants of collaboration in the literature consulted [37]. However, communication among actors represented in this study was an empirical manifestation of collaboration. It involved communicating to share information, to provide instructions and to seek support from internal and external bodies. These differences may be due to contextual factors such as the culture and values of individuals and the organization [37].

Many authors in the fields of health and education have proposed models for interprofessional collaboration [27,30,37]. Many components of the proposed model for secondary school-based collaborative practices that promote healthy eating and physical activity are documented in the literature on health and education [30,37]. In addition, context, a component of the proposed model, is fundamental to the practice of collaboration [28] in health promotion in schools. In education, the determinants of collaboration are classified under inputs and outputs [30]. In this study, the results obtained led us to present determinants and manifestations of collaboration under three separate headings: individual, team, and organization (determinants); and commitment to a project, communication, and co-ordination (manifestations). Further studies are needed to enrich the proposed model.

\section{Strengths of the study}

This is one of the first studies focused on the empirical manifestations of collaboration in the context of health promotion in secondary schools. Several measures have been taken to ensure the scientific rigour of the study. Data triangulation from multiple sources, data coding performed by at least two researchers, analysis using an inductive and iterative method, regular team meetings, a logbook to ensure correspondence between data and their interpretation and an in-depth understanding of collaborative practices are measures that could help to increase the credibility of the 
18

Promotion of Healthy Eating and Physical Activity in Schools

Bouchard, Gallagher, Soubhi, Bujold, \& St-Cyr

Journal of Research in Interprofessional Practice and Education

Vol. 5.1

May 2015 multiple-case study. Steps taken to increase the reliability of the study include in-depth description of the cases, a description of the stages of the study, two interviews conducted with each key informant, data triangulation from multiple sources, and data interpretation and analysis by at least two researchers. The in-depth description of the cases and of the manifestations of collaborative practices facilitates the identification of similar situations where the results could be transferable.

\section{Limitations of the study}

This study has limitations attributable to the units of analysis: the individuals and the significant activities. Since it was not possible to meet with more than two general informants in two out of the three cases to identify the significant activities, this may have affected the identification of other health promotion activities that involved collaborative practices; for instance, an eating activity involving a discussion between a French and a biology teacher. Some general informants selected by the school's administration at the time of data collection were perhaps not the best informed about school activities. Moreover, while the limited number of significant activities selected-two per case-helped identify manifestations of collaboration specific to these activities, they limit the external validity of the study. In addition, since it was impossible to observe all the events related to each of the selected activities, there might have been other manifestations. This would have required much more time in the field. Other relevant promotional activities conducted in the schools (annual day devoted to winter sports, breakfasts, etc.) were not considered because the general informants we met did not identify them with collaborative practices. However, a study of these activities might have identified other manifestations of collaboration.

Another limitation of this study is that it was conducted in one region of Québec. There are numerous public secondary schools across the province and each presents a unique context for promoting healthy eating and physical activity. Moreover, despite the various data collection methods, some of the manifestations (to take responsibility, to accept an idea) were not spontaneously identified or observed for Cases 2 and 3. It is possible that these manifestations were present but we were not able to identify them. One wonders how many more manifestations of collaboration could have been identified were there written documents that described all the work related to the activities examined. As it stands, the lack of documentation observed in the field could be a potential barrier to planning future health promotion activities.

Conducting a study in secondary schools is a complex initiative requiring a great deal of commitment. Recruiting schools and general informants, as well as planning meetings to conduct interviews, were labour-intensive stages of the process. Time constraints and the availability of teaching staff, especially when dealing with the school calendar and their individual schedules, were limiting factors during the data collection and analysis period. However, despite these limitations, the study results suggest the presence of collaborative practices in the field in activities promoting healthy eating and physical activity. 
Promotion of Healthy Eating and Physical Activity in Schools

Bouchard, Gallagher, Soubhi, Bujold, \& St-Cyr
Journal of Research in Interprofessional Practice and Education

Vol. 5.1

May 2015

\section{Journal of Research in Interprofessional Practice and Education}

This study advances knowledge on a subject that has been little explored in health promotion. Several empirical manifestations of collaborative practices in schools have been identified and an empirical model of collaboration in school-based health promotion has been developed from the results. However, it is necessary to continue identifying these practices in schools in order to assess their impact. The empirical description of collaborative practices also provides information necessary to develop a questionnaire for a larger-scale study, while the tools developed (such as the interview guide and event observation grid) could be adapted for other studies in this area. It would be useful to extend the study of collaborative practices to elementary schools and to explore the role of a school's physical environment on collaborative practices in activities promoting healthy eating.

The results of this study can help health promotion stakeholders think more creatively about practices to promote health and opportunities for collaboration in promoting the health of young people. For instance, documenting the history of activities could be used as a strategy to facilitate the repetition of activities over time.

\section{Conclusion}

Schools can play an important role in promoting healthy eating and physical activity [5]. This study is a first step in the conceptualization of school-based collaborative practices in health promotion involving stakeholders from various fields. In Quebec, collaborative practices in secondary schools among teaching and non-teaching staff that promote healthy eating and physical activity have not been documented in the literature. This study has highlighted many manifestations of collaboration in the promotion of these activities in three public schools. A model incorporating several components illustrates these manifestations, thus providing a foundation for documenting those practices. As such, it is the first step in developing knowledge about an essential component of health promotion.

\section{Acknowledgements}

The authors would like to thank the Réseau de recherche en interventions en sciences infirmières du Québec (RRISIQ), the Université du Québec à Chicoutimi, and the Université de Sherbrooke for their financial assistance.

\section{Note}

1. Fictitious names were given to these people in order to maintain confidentiality and to make the text more appealing.

\section{References}

1. Candeias, V., Armstrong, T.P., \& Xuereb, G.C. (2010). Diet and physical activity in schools: Perspectives from the implementation of the WHO global strategy on diet, physical activity and health. Canadian Journal of Public Health, 101(S2), S28-230.

2. Sassi, F. (2010). Lobésité et l'économie de la prévention : Objectif santé. Paris, France : Paris OCDE.

3. Lavelle, H.V., Mackay, D.F., \& Pell, J.P. (2012). Systemic review and meta-analysis of school-based interventions to reduce body mass index. Journal of Public Health, 34(3), 360-369.

4. Ministère de la Santé et des Services sociaux. (2010). Vision de la saine alimentation. Pour la création d'environnements alimentaires favorables à la santé. Québec, QC : Gouvernement du Québec, Service de la promotion des des saines habitudes de vie. 
20

Promotion of Healthy Eating and Physical Activity in Schools

Bouchard, Gallagher, Soubhi, Bujold, \& St-Cyr

Journal of Research in Interprofessional Practice and Education

Vol. 5.1

May 2015
5. Boucher, D., \& Côté, F. (2008). Facteurs influençant une saine alimentation chez des adolescents: Revue de littérature destinée a l'infirmière en milieu scolaire. L'infirmière clinicienne, 5(1), 63-70.

6. Cardon, M.G., Van Acker, R., Seghers, J., De Martelaer, K., Haerens, L.L., \& De Bourdeaudhuij, M.M.I. (2012). Physical activity promotion in schools: Which strategies do schools (not) implement and which socioecological factors are associated with implementation? Health Education Research, 27(3), 470-483.

7. Québec en forme. (2012). Pour une vision commune des environnements favorables à la saine alimentation, à un mode de vie physiquement actif et à la prévention des problèmes reliés au poids. Québec, QC : Gouvernement du Québec.

8. Harvey, G. (2010). Pour une approche globale à la santé en milieu scolaire. In Grenier, J., Otis, J., \& Harvey, G. (Eds.), Faire équipe pour l'éducation à la santé en milieu scolaire. (pp. 49-62). Québec, QC: Presses de l'Université du Québec.

9. Ordre des infirmières et infirmiers du Québec. (2012). Standards de pratique pour l'infirmière en santé scolaire. Montréal, QC : OIIQ.

10. Gonzalez-Suarez, C., Worley, A., \& Grimmer-Somers, K. (2009). School-based interventions of childhood obesity: A meta-analysis. American Journal of Preventive Medicine, 37(5), 418-427.

11. Ministère de la santé et des Services sociaux (2012). La santé des jeunes du secondaire au Québec: Santé physique et habitudes de vie. Québec, QC : Gouvernement du Québec.

12. Réseau du sport étudiant du Québec. (2012). Enquête québécoise sur la malbouffe. Québec, PQ: Réseau du sport étudiant du Québec.

13. Lipnowski, S., \& Leblanc, C. (2012). Une vie saine et active: Des directives en matière d'activité physique chez les enfants et les adolescents. Société canadienne de pédiatrie, comité d'une vie active saine et de la médecine sportive. URL: http://www.cps.ca/francais/enonces/HAL/HAL1202.htm [June 15, 2012].

14. Société canadienne de physiologie de l'exercice. (2011). Directives canadiennes en matière d'activité physique à l'intention des jeunes âgés de 12 à 17 ans. Ottawa, ON: Société canadienne de physiologie de l'exercice.

15. Baril, G., Ouimet, A-M., Bergeron, P., Séguin-Tremblay, R., \& Gauthier, A. (2012). Ados: 12-14: Les dimensions socioculturelles des pratiques alimentaires et d'activité physique des adolescents. Québec, QC : Institut national de santé publique.

16. Ylihärsilä, H., Kajentie, E., Osmond, C., Forsén, T., Barker, D.J., \& Erickson, J.G. (2008). Body mass index during childhood and adult body composition in men and women aged 56-70 y. The American Journal of Clinical Nutrition, 87, 1769-1775.

17. Tounian, P., \& Girardet, J. (2001). Lobésité de l’enfant: Une maladie qui met en jeu le pronostic vital. In Caïus, B., \& Benefice, E. (Eds.), Habitudes alimentaires, activité physique et surpoids chez des adolescents. (pp. 531-542). Paris : Masson.

18. Caïus, N., \& Benefice, E. (2002). Habitudes alimentaires, activité physique et surpoids chez les adolescents. Revue d'épidémiologie et de santé publique, 50(6), 531-542.

19. Croghan, E. (2005). Supporting adolescents through behavior change. Nursing Standard, 19(34), 50-53.

20. Parcel, G.S., Kelder, S.H., \& Basen-Engquist, K. (2000). The school as a setting for health promotion. In Poland, B.D., Green, L.W., and Rootman, I. (Eds.), Settings for health promotion: Linking theory and practice. (pp. 86-137). London: Sage Publications Inc.

21. Veugelers, P.J., \& Fitzgerald, A.L. (2005). Effectiveness of school programs in preventing childhood obesity: A multilevel comparison. American Journal of Public Health, 95(3), 432-435.

22. Secrétariat du Réseau intersectoriel de promotion des modes de vie sains, Groupe de travail fédéralprovincial-territorial sur les modes de vie sains, \& Comité consultatif F-P-T sur la santé de la population et la sécurité de la santé. (2005). La Stratégie pancanadienne intégrée en matière de modes de vie sains. Ottawa, ON: Gouvernement du Canada.

23. Ministère de l'Éducation, du Loisir et du Sport. (2007). Pour un virage en santé à lécole. Politiquecadre pour une saine alimentation et un mode de vie physiquement actif. Québec, QC : Bibliothèque et Archives nationales du Québec.

24. Martin, C., \& Arcand, L. (2005). École en santé. Guide à l'intention du milieu scolaire et de ses partenaires. Pour la réussite éducative, la santé et le bien-être des jeunes. Québec, QC : Ministère de l'Éducation, du Loisir et du Sport.

25. D’Amour, D., Goulet, L., Labadie, J-F., San Martin-Rodriguez, L., \& Pineault, R. (2008). A model and typology of collaboration between professionnals in healthcare organizations. BMC Health Services Research, 8(188), 1-14. 
21

Promotion of Healthy Eating and Physical Activity in Schools

Bouchard, Gallagher, Soubhi, Bujold, \& St-Cyr

Journal of Research in Interprofessional Practice and Education

Vol. 5.1

May 2015
26. D’Amour, D., Goulet, L., Pineault, R., Labadie, J.F., \& Remondin, M. (2003). Comparative study of inter-organizational collaboration and its effects in four Quebec socio-sanitary regions: The case of perinatal care. Montréal, PQ : Groupe de recherche interdisciplinaire en santé. Université de Montréal.

27. St-Cyr Tribble, D., Gallagher, F., Vanasse, A., Doré, C., Archambault, J., \& Fortin, M. (2007). Programme d'intervention fondé sur un modèle de collaboration interprofessionnelle et de promotion de l'autosoin auprès des diabétiques. Ottawa, ON: Fondation canadienne de la recherche sur les services de santé.

28. Deschênes, B., Jean-Baptiste, A., Matthieu, É., Mercier, A-M., Roberge, C., \& St-Onge, M. (2013). Guide d'implantation du partenariat de soins et de services. Vers une pratique collaborative optimale entre intervenants et avec le patient. Montréal, QC: Réseau universitaire intégré de santé de l'Université de Montréal.

29. Zwarenstein, M., Goldman, J., \& Reeves, S. (2009). Interprofessional collaboration: Effects of practice-based interventions on professional practice and healthcare outcomes. Cochrane Database Of Systematic Reviews, Issue 3. Art. No.: CD000072.

30. Dionne, L. (2003). La collaboration entre collègues comme mode de développement professionnel chez l'enseignant: Une étude de cas. Doctoral dissertation (D-1045). Montréal, QC : Université du Québec à Montréal.

31. Landry-Cuerrier, J. (2007). Enquête sur les perceptions et les pratiques de collaboration d'enseignants montréalais de l'ordre primaire. Doctoral dissertation (D-1529). Montréal, QC : Université du Québec à Montréal.

32. Martin-Rodriguez, S.L., Beaulieu, M-D., D’Amour, D., \& Ferrada-Videla, M. (2005). The determinants of successful collaboration: A review of theoritical and empirical studies. Journal of Interprofessional Care, 19(S1), 132-147.

33. Beaumont, C., Lavoie, J., \& Couture, C. (2010). Les pratiques collaboratives en milieu scolaire: Cadre de référence pour soutenir la formation. Québec, QC : Centre de recherche et d'intervention sur la réussite scolaire, Université Laval.

34. Grossman, C.S., \& Valiga, M.T. (2013). The new leadership challenge. Creating the futureof nursing. Philadelphia, PA: F.A. Davis Company.

35. Association des infirmières et infirmiers du Canada. (2009). Le leadership de la profession infirmière. Énoncé de position. Ottawa, ON: AIIC.

36. Ministère de l'Éducation du Québec. (2006). Programme de formation de l'école québécoise: Enseignement secondaire, premier cycle. Québec, QC : Gouvernement du Québec.

37. D’Amour, D. (2002). La collaboration professionnelle: Un choix obligé. In Goulet, O., \& Dallaire, C. (Eds.), Les soins infirmiers: Vers de nouvelles perspectives. (pp. 339-363). Boucherville, QC : Gaëtan Morin.

38. Yin, R.K. (2003). Case study research: Design and methods, 3rd edition. Thousand Oaks: Sage Publications.

39. Yin, R.K. (2014). Case study research: Design and methods, 5th edition. London: Sage Publications.

40. Bouchard, M-C. (2014). Pratiques collaboratives en milieu scolaire secondaire dans la promotion d'une saine alimentation et de l'activité physique. Thèse de doctorat. Sherbrooke, QC: Université de Sherbrooke.

41. Association of Administrators of English Schools of Québec (AAESQ), Centrale des syndicats du Québec (CSQ), Fédération des professionnelles et professionnels de l'éducation du Québec (FPPE), Fédération des syndicats de l'enseignement (FSE), Fédération du personnel de soutien scolaire (FPSS), Fédération québécoise des directeurs et directrices d'établissement d'enseignement (FQDE), Quebec Federation of Parent's Committees (FCPQ), \& Quebec Provincial Association of Teachers (QPAT). (2003). The educational project and the success plan of the school. Quebec, QC : AAESQ, CSQ, FPPE, FSE, FPSS, FQDE, FCPQ, QPAT.

42. Roy, S.N. (2006). Létude de cas. In Gauthier, B. (Ed.), Recherche sociale. De la problématique à la collecte de données. (pp. 159-184). Québec, QC : Presses de l'Université du Québec.

43. Laperrière, A. (2006). L'observation directe. In Gauthier, B. (Ed.), Recherche sociale. De la problématique à la collecte des données. (pp. 269-291). Québec, QC : Presses de l’Université du Québec.

44. Miles, M.B., \& Huberman, M.A. (2003). Analyse des données qualitatives, $2^{\text {nd }}$ edition (M. Hlady Rispal, Trans.). Paris : De Boeck Université. 